\title{
FONOTAKTIK DAN PEMBENTUKAN SUKU KATA BAHASA SANGIR
}

\author{
Evi Martika D. Kasiahe \\ kasiaheevi@gmail.com \\ Jenny Pakasi \\ peningp@yahoo.com

\section{Pascasarjana Program Studi Linguistik Universitas Sam Ratulangi}

\begin{abstract}
Phonotactics adjust possible phonemic sequences in a particular language. The phonemic sequence applies either for words, or syllables. Thus, syllable forming process requires phonotactic rules applied in the language. There are few researches that focus on both phonotactics and syllable forming process simultaneously, although there is a close relationship between those two. This research mainly focuses on finding out the relationship between phonotactics and syllable forming process using Sangirese language as the research object to find out how Sangirese syllable forming process, syllable structure, and phonotactic rules are applied. The primary data were collected from several native speakers of Sangirese, and the data were analysed using theories from O'Grady and Dobrovolsky (1997) and from Chaer (2009). The study results show first, that the syllable of Sangerese has a complete element namely Nucleus (N), Onset $(O)$ and coda $(C)$. Second, the Sangerese language has four structures namely $V, C V, V C$ dan CVC and it is found out that in Sangerese language there is no syllable structure such as, CCV, CCVC, CCVCC, VCC, VCC, CCCV, CCCVC. Third, in the phonotactic of Sangerese, it is found out that there is no two consonants in lined either in the beginning, in the middle or at the end of syllable accept if the first consonant is a nasal consonant such as $\mathrm{In} / \mathrm{m} /$ and $/ \eta$, /, therefore the coda of the syllable of Sangerese in general is in nasal consonant.
\end{abstract}

Keywords: phonotactics, syllable, Sangirese language.

\section{PENDAHULUAN}

Objek material kajian linguistik adalah bahasa, salah satu bagian penting dari bahasa adalah bunyi-bunyi ujar. Fonologi merupakan cabang linguistik yang kajiannya berfokus pada persoalan bunyi. Fonologi mengkaji tentang bunyi-bunyi bahasa, sebagai satuan terkecil di dalam suatu ujaran termasuk juga gabungan antar bunyi yang membentuk silabel atau suku kata. Selain itu, bidang kajian fonologi juga mencakup unsur-unsur suprasegmental dari suatu ujaran seperti, tekanan, nada, hentian dan durasi. Suku kata dalam hal ini masih merupakan bidang kajian fonologi, suku kata perlu dibedakan dengan morfem yang merupakan bidang kajian dari morfologi. Suku kata tidak memiliki makna sedangkan morfem memiliki makna. Pada tataran fonologi, istilah silabel atau suku kata menunjuk pada sejumlah deretan baik 
konsonan atau vokal dan ciri-ciri lain seperti jangka dan tekanan, atau sebuah konsonan atau sebuah vokal yang dalam bahasa tertentu dianggap sesuai dan merupakan satu kesatuan yang dapat dianalisis lebih lanjut. Sedangkan secara fonetis istilah silabel menunjuk pada sederatan bunyi bahasa yang memiliki puncak kenyaringan (tidak mencakup faktor lain seperti tekanan dan tinggi nada) di antara dua minimum kenyaringan. Umumnya yang menjadi puncak kenyaringan adalah vokal dan bukan konsonan (Robins 1992:160).

Setiap bahasa memiliki bentuk dan struktur suku kata yang berbeda-beda sebab memiliki kaidah pembentukan yang berbeda pula. Di dalam studi fonologi pembentukan suku kata sangat dipengaruhi oleh kaidah fonotaktik yang berlaku di dalam suatu bahasa. Michael Dobrovolskyand William DO'Grady menulis (1997:56) "Phonotactis, the set of constraints on how sequence of segments pattern, forms part of a speaker's knowledge of the phonology of his or her language" artinya "Fonotaktik, serangkaian aturan tentang urutan pola segmen, merupakan bagian dari pengetahuan pembicara tentang fonologi bahasanya”. Sedangkan Kentjono dan Sunarto (1990:34) mendefiniskan fonotaktik sebagai deretan atau urutan fonem yang dimungkinkan di dalam suatu bahasa serta diakui oleh penutur bahasa tersebut. Setiap bahasa memiliki kententuan-ketentuan fonotaktik yang berbeda dan dengan sendirinya akan memengaruhi pembentukan suku kata dalam bahasa tersebut. Misalnya, dalam bahasa Indonesia tidak dijumpai suku kata dengan akhir /c/ atau /j/, sedangkan dalam bahasa Inggris suku kata seperti itu ada, seperti dalam kata catch dan judge. Sebaliknya, dalam bahasa inggris tidak dijumpai suku kata yang mulai dengan /y/, sedangkan dalam bahasa Indonesia suku kata seperti itu dijumpai pada kata [nganga] dan [ngilu].

Dalam artikel ini penulis mengkaji tentang fonotaktik dan pembentukan suku kata dalam bahasa Sangir. Topik yang diangkat dalam artikel ini, baik tentang fonotaktik dan pembentukan suku kata maupun tentang bahasa Sangir, pernah muncul dalam beberapa penelitian sebelumnya tetapi dengan fokus dan tujuan penelitian yang berbeda-beda. Penelitian yang berhubungan dengan fonotaktik dan suku kata pernah diangkat oleh Namsyah Hot Hasibuan (1996) dalam tesisnya yang berjudul "Fonotaktik dalam Suku Kata Bahasa Indonesia". Tesis ini bertujuan untuk menemukan kaidah penyukuan dan kaidah fonotaktik yang dipakai dalam bahasa Indonesia. Sudarmo (2016) dalam artikelnya "Fonotaktik Bahasa Banjar" yang berfokus pada sistem fonotaktik dengan Bahasa Banjar sebagai objek kajiannya. Tulisan lain tentang topik ini ditemukan juga dalam artikel I Wayan Pastika (2012) yang berjudul "Kelemahan fonologis Ejaan Bahasa Indonesia yang Disempurnakan" tulisan ini berfokus pada kelemahan fonologis dalam ejaan bahasa Indonesia yang dengan sendirinya berpengaruh pada pembentukan suku kata bahasa Indonesia. 
Dari penelitian-penelitian terdahulu di atas tampak bahwa hanya satu peneliti yang membahas tentang fonotaktik dan hubungannya dengan suku kata yaitu Namsyah Hot Hasibuan. Sedangkan Sudarmo berfokus pada fonotaktik bahasa Banjar sehingga pembahasan yang dijumpai dalam tulisan hanya membahas tentang urutan fonem yang dimungkinkan dalam bahasa Banjar. Meskipun akhirnya Sudarmo juga sampai pada uraian struktur suku kata bahasa Banjar yang terbentuk berdasarkan kaidah-kaidah fonotaktik bahasa banjar yang telah diuraikannya lebih dulu. Sementara I Wayan Pastika, berfokus adalah kelemahan fonologis yang dalam uraiannya terlihat bahwa kelemahan fonologis ini sebenarnya juga mencakup tentang kaidah fonotaktik bahasa Indonesia yang berpengaruh pada pembentukkan suku kata bahasa Indonesia. Tetapi ini bukan fokus kajian Pastika karena hal ini tidak disebutkan secara eksplisit dalam judul artikel. Artikel ini akan berfokus pada dua hal yaitu fonotaktik dan pembentukan suku kata dalam bahasa Sangir, yakni melihat sejauh mana kaidah fonotaktik suatu bahasa sangat berpengaruh pada pembentukan suku kata.

Sejauh ini juga telah ditemukan beberapa penelitian yang menggunakan bahasa Sangir sebagai objek penelitian. G. Bawolle (1978) dalam bukunya yang berjudul "Struktur Bahasa Sangihe" berfokus mengkaji struktur bahasa Sangir. G. Bawolle, J. Akun Danie dan Toding Dalu (1981) "Morfologi Bahasa Sangihe" masih menggunakan bahasa Sangir sebagai objek kajian tetapi dengan fokus kajian pada bidang morfologi. J. Akun Danie dkk (1998) "Geografi Dialek Bahasa Sangir" dengan fokus pembahasan pada dialek-dialek bahasa Sangir dan pemetaan tentang dialek-dialek bahasa sangir sebagaimana tersebar di wilayah Kabupaten Kepulauan Sangihe. Paul Nebart dkk (1985) dalam bukunya "Sastra Lisan Sangir Talaud" menguraikan tentang macam-macam sastra lisan yang dijumpai dalam masyarakat Sangihe. Dari penelitian-penelitian ini tampak bahwa belum ada penelitian yang menggunakan bahasa Sangir sebagai objek penelitian dengan fokus perhatian pada aspek fonologi bahasa Sangir. Seperti pada bahasa-bahasa lain, aspek fonologi tetap merupakan suatu bagian penting dari semua bahasa, tidak terkecuali juga pada bahasa Sangir. Penulis merasa tertantang untuk membahas aspek fonologi bahasa sangir dengan fokus kajian pada aspek fonotaktik dan pembentukan suku kata dalam bahasa Sangir.

Bahasa Sangir dipilih sebagai objek kajian dalam artikel ini, karena bahasa Sangir merupakan bahasa ibu dari penulis yang adalah orang Sangir asli. Sehingga artikel ini merupakan wujud kecintaan dan kepedulian penulis terhadap bahasa Sangir. Dalam penelitian ini, penulis memang mengangkat dua topik yaitu tentang fonotaktik dan pembentukan suku kata, penulis tidak bermaksud untuk menjelaskan kedua topik secara 
detail tetapi lebih fokus pada bagaimana kedua topik saling berhubungan satu dengan yang lain, karena itu dua topik harus dibahas sekaligus dan tidak boleh dipisahkan. Masalah yang dibahas dalam tulisan ini yaitu bagaimana pembentukan suku kata bahasa Sangir? bagaimana struktur suku kata bahasa Sangir? bagaimana kaidah fonotaktik dalam pembentukan suku kata bahasa Sangir? Berdasarkan rumusan masalah tersebut maka tujuan dari penelitian ada tiga yaitu, menjelaskan pembentukan suku kata bahasa Sangir, mengidentifikasi struktur suku kata bahasa Sangir dan menjelaskan kaidah fonotaktik dalam pembentukan suku kata bahasa Sangir. Dalam artikel ini dideskripsikan tentang metode penelitian yang digunakan, landasan teori yang digunakan, pembentukan suku kata, struktur suku kata, fonotaktik bahasa Sangir dalam pembentukan suku kata dan beberapa poin simpulan dari hasil pembahasan.

\section{METODOLOGI}

Penelitian ini menggunakan pendekatan kualitatif untuk menemukan data dari sumbersumber data yang ada. Data yang diperoleh dari penelitian yang dilanjutkan dengan proses analisis dan penyimpulan. Dengan menggunakan pendekatan kualitatif maka data dan hasil penelitian yang dituangkan dalam artikel ini sepenuhnya adalah objektif. Metode yang digunakan dalam penelitian ini adalah metode deskriptif. Metode deskriptif adalah metode yang bertujuan untuk mendeskripsikan atau menjelaskan peristiwa atau kejadian secara objektif. Menurut Sudaryanto (1993:62), dengan menggunakan metode deskriptif hasil yang diperoleh adalah berupa pemerian bahasa apa adanya yang terperinci dan mendalam. Data yang berupa kata- kata bahasa Sangir ini dikumpulkan lewat penelitian lapangan dengan menggunakan 5 orang informan yang merupakan penutur asli bahasa Sangir. Metode yang dipakai untuk menganalisis data hasil temuan ini adalah meto berupa kata-kata bahasa Sangir yang dikumpulkan baik melalui studi pustaka, yaitu dengan mengumpulkan kata-kata bahasa Sangir yang diperoleh dalam berbagai buku atau penelitian terdahulu tentang bahasa Sangir, maupun melalui penelitian lapangan dan beberapa informan yang merupakan penutur asli bahasa Sangir. Data yang ada, dikumpulkan berdasarkan suku kata maupun kaidah fonotaktik yang berlaku di dalam bahasa Sangir. Baik berdasarkan jumlah suku kata dalam setiap kata maupun kaidah fonotaktik yang mencakup deretan fonem atau urutan-urutan fonem antara lain beruapa, deret vokal, diftong, deret konsonan dan kluster. Data yang sudah terkumpul ini dianalisis dengan metode analisis deskriptif kualitatif dalam bentuk pengklasifikasian data dan analisis untuk menemukan sturuktur suku kata bahasa Sangir dan kaidah fonotaktik yang berlaku baik dalam kata maupun suku kata bahasa Sangir. 


\section{PEMBENTUKAN SUKU KATA BAHASA SANGIR}

Pembentukan suku kata dimulai dengan mencari puncak kenyaringan atau sonoritas dalam sebuah kata, punyak kenyaringan dalam suatu kata biasanya adalah sebuah bunyi vokal. Bunyi vokal ini disebut sebagai puncak silabel (Chaer 2009:57). Satu kata bisa saja memiliki satu, dua atau lebih puncak kenyaringan yang menandakan bahwa kata tersebut terdiri dari satu, dua atau lebih suku kata. Misalnya kata kaeng 'makan' dalam bahasa Sangir, yang dilafalkan menjadi [kân] puncak kenyaringannya terletak pada vokal /â/ yang berada di

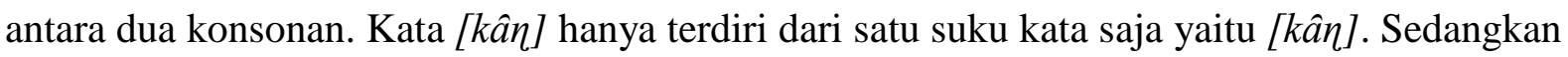
kata [lohan] 'lubang' memiliki dua puncak silabel yaitu vokal /o/ dan /a/ sehingga dengan

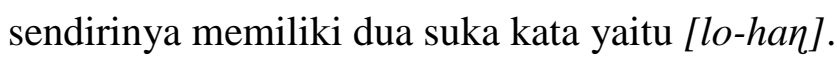

Meskipun awal pembentukan suku kata dimulai dengan mencari puncak kenyaringan dalam suatu kata, tetapi seperti apa deret vokal dan konsonan yang diijinkan atau dimungkinkan di dalam suatu bahasa hal ini ditentukan berdasarkan kaidah bahasa masingmasing yang disebut sebagai kaidah fonotaktik. Langkah-langkah untuk menentukan batas suku kata seperti yang akan dijelaskan dalam uraian dan gambar di bawah ini berlaku untuk semua bahasa (DobrovolskyMichael and William DO' Grady menulis 1997:73), tetapi pembatasan deretan konsonan dan vokal untuk setiap silabel semua itu diatur berdasarkan kaidah fonotaktik yang diterima dalam bahasa yang hendak menjadi objek kajian. Berikut ini ada diuraikan proses pembentukan suku kata di dalam bahasa Sangir.

\section{Langkah 1}

Pada bagian ini, yang harus diperhatikan lebih dahulu adalah bunyi vokal yang ada di dalam sebuah kata. Dengan langkah pertama ini hendak dimaksudkan pentingnya vokal pada setiap suku kata. Vokal yang merupakan nukleus ini biasa disimbolkan dengan (N) yang dihubungkan dengan $\sigma$ di atasnya yang merupakan penanda batas suku kata. Seperti tampak di bawah pada kata-kata [kân] 'makan',[səmbau']'satu'[biwihə] 'bibir'dan [batiawa]'mimpi'.

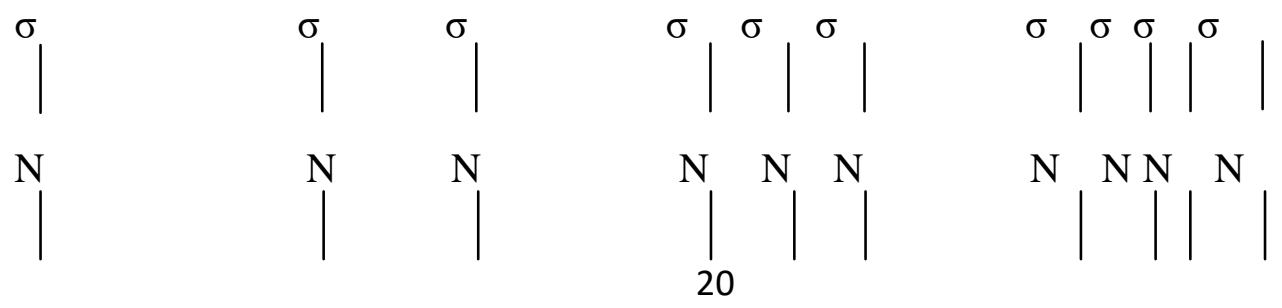



kâ $\eta$
$\mathrm{s} \partial \mathrm{m} \mathrm{b} \mathrm{au}^{?}$
bi wi hê
ba ti a wa

Dari gambar di atas dapat dilihat bahwa vokal /â/ menjadi puncak dari suku kata [kân] sehingga kata [kân] hanya membentuk satu suku kata saja yaitu [kân]. Kata selanjutnya yaitu kata səmbau memiliki dua puncak silabel yaitu pada vokal /ə/ dan diftong /au/. Kata biwihê yang memiliki lebih banyak vokal dengan sendirinya memiliki tiga puncak suku kata atau nukleus, yaitu pada vokal /i/, /i/ dan /ê/. Pada kata [batiawa] ditemukan empat nukleus yaitu pada vokal / $/$ /, / $/$ /, / $/$ / dan /a/ lagi, perhatikan dua deretan vokal yaitu dan /ia/ keduanya berada pada dua suku kata yang berbeda. Karena /ia/ ada deret vokal dan bukan diftong seperti /au/ pada kata səmbau?

\section{Langkah 2}

Langkah kedua adalah memerhatikan konsonan yang berada disebelah kiri inti suku katayang sesuai dan secara fonotaktik diterima dalam bahasa tersebut atau tidak menyalahi kaidah bahasa tersebut, konsonan-konsonan ini disebut sebagai awalan suku kata atau onset yang disimbolkan $\mathrm{O}$ yang dihubungkan vokal disebelah kanan.
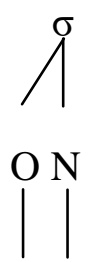

$\mathrm{k}$ â $\eta$
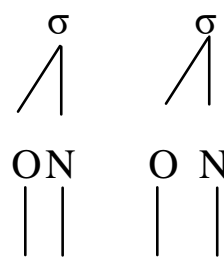

$\mathrm{s}$ ə $\mathrm{m} \mathrm{b} \mathrm{au}^{\text {? }}$
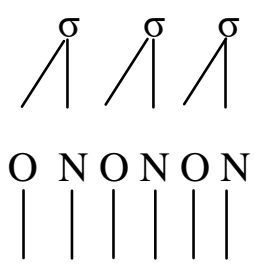

b i w i h ê
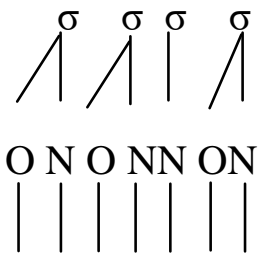

b a 1 i a w a

Pada kata pertama [kân] konsonan yang berada disebelah kanan inti suku kata adalah konsonan $/ k$ / sehingga yang menjadi onset pada suku kata [kân] adalah $/ k /$. Ada hal menarik perlu diperhatikan pada kata kedua dalam contoh di atas, perhatikan bahwa $/ s /$ menjadi onset karena berada disebelah kanan vokal /a/ sedangkan / $b /$ menjadi onset karena berada disebelah kanan diftong /au/. Onset atau awalan suku kata tidak hanya terdiri dari satu konsonan saja, onset dapat berupa gugus konsonan sejauh gugus konsonan tersebut dimungkinkan atau berterima di dalam suatu masyarakat penutur bahasa tertentu (DobrovolskyMichael and O'Grady William D menulis 1997:73). /m/ pada kata [səmbau'] di atas tidak merupakan onset karena dalam bahasa Sangir tidak ditemukan gugus konsonan $/ \mathrm{mb} /$ sebaliknya $/ \mathrm{mb} /$ adalah 
merupakan deret konsonan sehingga keduanya berada dua suku kata berbeda. Posisi $/ \mathrm{m} / \mathrm{di}$ sebelah kiri inti silabel pertama yaitu vokal /ə/ pada kata /səmbau'/ akan dijelaskan pada langkah ketiga berikut ini.

\section{Langkah 3}

Pada bagian ketiga ini adalah memerhatikan konsonan yang tersisa disebelah kanan suku kata, konsonan yang tersisa ini disebut sebagai koda suku kata yang disimbolkan dengan (C) yang terhubung dengan inti suku kata yang terletak di sebelah kiri. Suku kata yang sudah terbentuk ini adalah merupakan satu kata yang dihubungkan dengan garis ke simbol $\mu$.

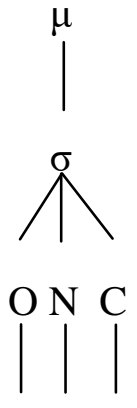

$\mathrm{k}$ â $\mathrm{\eta}$
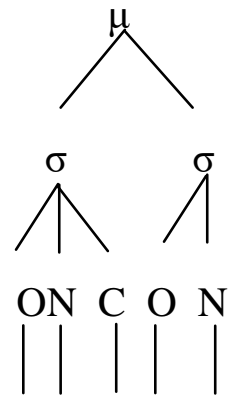

$\mathrm{s} \partial \mathrm{m} \mathrm{b} \mathrm{au}^{\text {? }}$
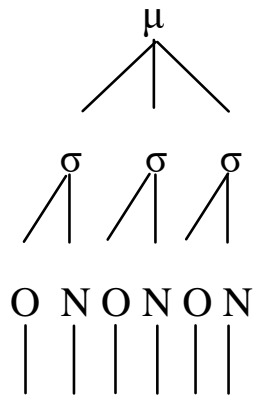

b i w i h ê
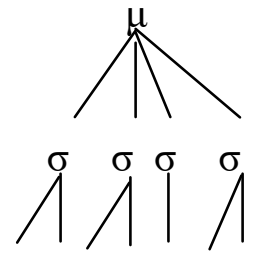

O N O NN ON

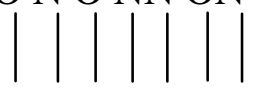

b a 1 i a w a

Sebelumnya telah diuraikan bahwa fonem $/ \mathrm{m} /$ yang berada di sebelah kiri diftong / $\mathrm{au} /$ yang merupakan inti dari suku kata kedua dalam kata [sambau'] tidak dapat menjadi onset karena dalam bahasa Sangir tidak ditemukan gugus konsonan $/ \mathrm{mb} /$, sehingga posisi $/ \mathrm{m} /$ yang berada disebelah kanan vokal / $/$ menjadi koda untuk suku kata pertama yang memiliki inti suku kata pada vokal /ð/. Perhatikan bahwa dari keempat kata yang diangkat untuk menjadi untuk menjadi contoh pada pembentukan suku kata bahasa Sangir di atas hanya satu suku kata dari satu kata saja yang ditemukan memiliki koda suku kata, hal ini dikarenakan dalam bahasa Sangir jarang ditemukan gugus konsonan, umumnya yang ditemukan adalah deret konsonan sehingga kedua konsonan yang berderet tersebut harus dipisah dang tidak boleh dipaksakan karena tidak berterima di dalam fonotaktik bahasa Sangir. Hail akan dibahas lebih lanjut pada pembahasan tersendiri tentang fonotaktik.

\section{STRUKTUR SUKU KATA BAHASA SANGIR}

Dengan memerhatikan pembentukan suku kata bahasa Sangir sesuai dengan tiga langkah yang telah digambarkan dan diuraikan di atas dapa dilihat bahwa dalam menentukan batas suku kata hal pertama yang diperhatikan adalah bunyi vokal di dalam suatu kata yang biasanya akan menjadi inti suku kata. Setelah inti suku kata ditemukan barulah diperhatikan deret konsonan atau gugus konsonan yang secara fonotaktik berterima dalam suatu bahasa 
tertentu (Robins 1992:163), sehingga dengan memerhatikan kaidah fonotaktik suatu bahasa barulah dapa ditentukan mana konsonan yang akan menjadi koda suku kata dan mana konsonan yang akan menjadi onset suku kata. Pembentukan suku kata dalam suatu bahasa dengan sendirinya juga harus memerhatikan gugus fonem di dalam bahasa itu sendiri.

Gugus fonem merupakan bagian dari struktur fonetis atau fonotaktik yang disadari oleh penutur bahasa yang bersangkutan sehingga pengucapan gugus fonem harus disesuaikan dengan struktur fonotaktik yang dimungkin dalam bahasa tersebut. Gugusan fonem biasanya dapat berupa gugus konsonan yang disebut kluster atau gugus vokal yang biasanya disebut diftong (Muslich 2008:69-72). Berikut ini akan diuraikan beberapa poin sehubungan dengan struktur suku kata bahasa Sangir baik menyangkut diftong, kluster, deret konsonan maupun deret vokal.

\section{Deret Vokal dan Diftong}

Alwi dkk. (1998:52) juga mengatakan deret vokal adalah hembusan nafas yang sama atau hampir sama, kedua vokal itu termasuk dalam suku kata yang berbeda. Misalnya, deret /ai/ pada kata [kain] adalah deret vokal karena kata ini terdiri atas dua suku kata yaitu [ka-in]. Jadi dari pendapat di atas dapat disimpulkan bahwa deret vokal merupakan gabungan dua atau lebih vokal yang berjajaran yang terdapat pada suku kata yang berbeda dan merupakan puncak kenyaringan ucapan. Berbeda dengan bunyi diftong yang dalam menentukan inti suku kata bunyi diftong telah diperhitungkan sebagai sebuah bunyi dan karena cirinya lebih dekat kepada vokal maka diftong dianggap sebagai sebuah vokal sehingga harus berada pada suku kata yang sama. Diftong dan deret vokal dalam bahasa Indonesia, misalnya /ai/ pada kata [sunai] adalah diftong sehingga kata [sunai] memiliki suku kata [su-nai] bukan [su-na-i] sedangkan pada kata [main], /ai/ adalah deret vokal sehingga kata [main] memiliki dua suku kata yaitu [ma-in] dan bukan satu suku kata saja yaitu [main].

Pembentukan suku kata bahasa Sangir di atas jika diperhatikanmembedakan antara difong dan deret vokal. Perhatikan /au'/ pada kata [sombau] dan /ial pada kata [batiawa], lau'/ adalah diftong sehingga kata [sambau'] memiliki suku kata [səm-bau']dan bukan [səm$\left.b a-u^{\prime}\right]$. Karena merupakan diftong $/ a u^{\prime} /$ dilafakan bersama sehingga keduanya secara otomatis berada di dalam satu suku kata yang sama.Sedangkan /ial pada kata [batiawa] adalah deret vokal sehingga keduanya ditulis secara terpisah dan berada pada dua suku kata yang berbeda [ba-ti-a-wa].Perhatikan beberapa contoh diftong dan deret vokal dalam katakata bahasa Sangir pada tabel berikut. 
Tabel 1.1

Diftong dan Deret Vokal

\begin{tabular}{|lc|lc|}
\hline \multicolumn{2}{|c|}{ Diftong } & \multicolumn{2}{c|}{ Deret Vokal } \\
\hline$s a m-b a u^{\prime}$ & 'satu' & $s a-r a-\varepsilon \eta$ & 'setelah' \\
\hline$n a u \eta$ & 'hati' & $b o-u^{?}$ & 'dari' \\
\hline
\end{tabular}

\section{Efisiensi Bunyi pada Vokal /e/ yang Dilafalkan /ə/ di BelakangVokal /a/Kecuali / $\varepsilon /$}

Dalam proses artikulasi kadang ditemukan ada kata-kata tertentu yang mengalami proses efisiensi bunyi hal ini dikarenakan suatu bunyi atau fonem di dalam suatu kata tidak berdiri sendiri melainkan saling berkaitan satu dengan yang lain di dalam suatu runtutan bunyi. Proses efisiensi ini membantu para penutur bahasa untuk dapat mengucapkan kata-kata tertentu dengan mudah. Penutur lebih memiliih melafalkan suatu kata dengan cara yang lebih mudah dilafalkan ketimbang melafalkannya sesuai urutan bunyi dalam kata tersebut. Di dalam bahasa Inggris proses efisiensi bunyi dapat dilihat di dalam kata parade yang oleh penutur bahasa Inggris diucapkan menjadi lebih efisien menjadi [preyd] sedangkan pada pengucapan tanpa efisiensi adalah [pərâd]. Proses efisiensi bunyi ini membuat kata parade yang sebenarnya memiliki dua suku kata ketika dilafakan tanpa efisiensi tetapi setelah efisiensi kata /parade/ kini hanya memiliki satu suku kata saja dengan inti silabelnya jatuh pada vokal /ey/. Dalam bahasa Sangir Efisiensi ini dapat terjadi pada ketika penutur hendak memperjelas suatu kata atau untuk mengatakan kata yang sama kedua kalinya.

Efisiensi bunyi dalam bahasa Sangir ditemukan pada kata-kata yang memiliki bunyi/ə/di belakang vokal /a/ sedangangakan bunyi / $/$ / di belakang vokal /a/ tidak mengalami efisiensi bunyi. Proses efisiensi bunyi pada vokal /ə/ juga memengaruhi pembentukan suku kata dalam bahasa Sangir. Perhatikan kata kaengyang dilafalkan menjadi [kân] sehingga hanya membentuk satu suku kata [kân] tanpa efisiensi bunyi pada vokal /ə/ kata kaeng dapat

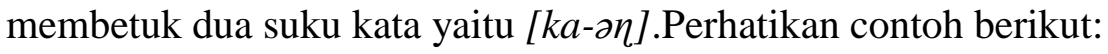

$$
\begin{array}{lll}
\text { Pelafalan awal tanpa efisiensi bunyi } & \text { : “dako e kaeng” } & \text { pergilah makan } \\
\text { Pelafalan kedua dengan efisiensi } & \text { : “dako e o } \text { kang” } & \text { pergilah makan } \\
& \text { (mengajak makan kedua kalinya) }
\end{array}
$$

Proses efisiensi bunyi yang juga terjadi pada kata dalokaeng yang menjadi [datokan]

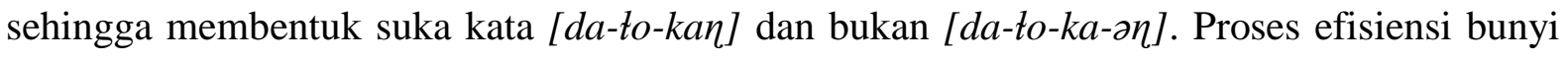
tidak terjadi pada jika vokal /e/ dilafakan dengan alofon /ع/. Seperti pada kata sakaeng 'perahu' dan kakiraeng 'cukuran'vokal /e/ yang berada di belakang vokal /a/ tidak mengalami

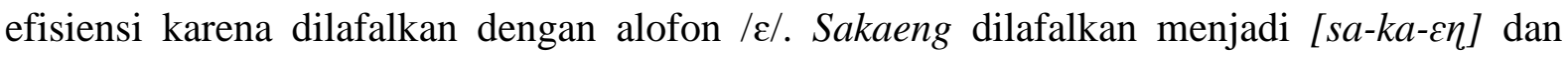


kakiraeng dilafalkan menjadi /ka-ki-ra-eng/. Kata-kata yang memiliki vokal / $/$ / di belakang vokal /a/ tidak mengalami proses efisiensi bunyi meski diucapkan dua kali untuk memperjelas maksud suatu ungkapan, sehingga kata-kata yang seperti ini dengan sendirinya tidak mengalami perubahan pada silabelnya.

\section{Vokal dan Konsonan}

Fonem-fonem yang berderet dalam satu suku kata yang membentuk urutan bunyi adalah berupa fonem vokal dan fonem konsonan. Tetapi deretan fonem yang membentuk bunyi ini memiliki struktur sedemikian rupa di dalam tiap suku kata sehingga membentuk struktur suku kata. Dengan memerhatikan pembentukan suku kata bahasa Sangir pada uraian sebelumnya maka dapat digambarkan bagaimana strukutur suku kata bahasa sangir, sesuai dengan urutan fonem yang berada dalam satu silabel tentu saja tetap dengan memerhatikan, deret vokal dan diftong maupun deret konsonan dan kluster.Struktur suku kata bahasa Sangiryang umum ditemukan terdiri dari konsonan $(\mathrm{K})$ dan vokal $(\mathrm{V})$ sehingga membentuk pola KVKVKV perhatikan suku kata pada kata[bawinê]di atas dengan pola KVKVKV menjadi [ba-wi$n e ̂]$.Berikut ini akan diuraikan struktur suku kata yang dijumpai dalam Bahasa Sangir.

Tabel 1.2

Struktur Suku Kata Bahasa Sangir

\begin{tabular}{|c|c|}
\hline Struktur Suku Kata & Contoh \\
\hline $\mathrm{V}$ & 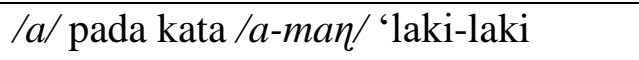 \\
\hline $\mathrm{KV}$ & /tu/pada kata /tu-hu/ 'iku \\
\hline VK & 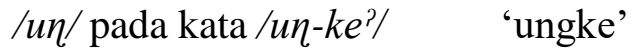 \\
\hline KVK & 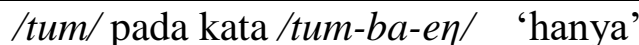 \\
\hline
\end{tabular}

Dari struktur suku kata yang ada dapat dilihat bahwa dalam bahasa Sangir jarang ditemukan konsonan berderet di dalam satu kata, sehingga hal ini juga memengaruhi pembentukan struktur suku kata. Dari tabel di atas tampak bahwa dalam bahasa Sangir ditemukan tiga struktur suku kata yaitu V, KV, VK dan suku kata lengkap atau utuh yaitu KVK. Karena hanya ada tiga struktur ini maka dalam bahasa Sangir tidak ditemukan suku kata dengan struktur KKV, KKVK, KKVKK, VKK, KVKK, KKKV, KKKVK. Tetapi ada satu pengecualian yang ditemukan dalam bahasa Sangir bahwa jika ada dua konsonan bereret dalam satu kata maka konsonan pertama adalah konsonan nasal. Meski berada dalam satu kata tetapi deret konsonan ini pada pembentukan suku kata akan akan terpisah dan tidak akan 
berada pada satu suku kata yang sama. Hal ini rupanya juga memengaruhi koda suku kata bahasa Sangir. Hal ini akan diuraikan lebih lanjut pada pembahasan selanjutnya tentang fonotaktik pada pembentukan suku kata bahasa Sangir.

\section{FONOTAKTIK PADA PEMBENTUKAN SUKU KATA BAHASA SANGIR}

Fonotaktik merupakan salah satu bagian dari fonologi yang mengatur urutan fonem yang membentuk sebuah kata tetapi juga suku kata. Dengan kata lain fonotaktik sebuah kata menjadi dasar bagi fonotaktik suku kata. Dengan fonotaktik maka dihasilkan bunyi yang dapat berterima dalam sebuah bahasa dan diterima oleh masyarakat penutur bahasa itu Fonotaktik membicarakan pola urutan bunyi, distribusi fonem, pola suku kata, gugus bunyi konsonan dan vokal, jenis-jenis gugus bunyi yang mungkin dan yang tidak mungkin pada tingkat kata atau antarkata dan suku kata.Aturan-aturan tersebut tidak sama pada semua bahasa, tetapi berbeda-beda.

Michael Dobrovolskyand William DO' Grady (1997) mengartikan fonotaktik sebagai seperangkat pembatas-pembatas tentang bagaimana pola deretan bunyi-bunyi (segmen) itu terbentuk, fonotaktik suatu bahasa merupakan bagian dari kemampuan dan pengetahuan fonologis yang dimiliki oleh penutur bahasa itu. Dengan fonotaktik dapat dihasilkan bunyi yang dapat berterima dalam sebuah bahasa dan diterima oleh masyarakat penutur bahasa. Fonotaktik bahasa Sangir yang dimaksudkan di sini adalah kaidah yang mengatur penjejeran fonem-fonem dalam kata maupun suku kata bahasa Sangir baik menunjukkan kemungkinan tata urutan fonem, maupun sistem yang terjadi dalam penjejeran fonem tersebut.

\section{Tidak Ditemukan Deret Konsonan, Kecuali Konsonan Pertama adalah Nasal}

Alwi dkk. (1998:79) mengatakan bahwa deret konsonan adalah gabungan dua konsonan atau lebih yang terjadi pada suku kata yang berbeda meskipun berdampingan. Sebelumnya telah diuraikan tentang struktur suku kata bahasa Sangir. Dengan memerhatikan beberapa contoh kata maupun suku kata dalam bahasa Sangir yang dipaparkan sebelumnya tampak bahwa dalam bahasa Sangir tidak ditemukan deretan konsonan baik pada awal kata, tengah kata dan akhir kata atau pada awal suku kata, tengah suku kata dan akhir suku kata, kecuali jika konsonan pertama adalah konsonan nasal. Penemuan ini menjadi indikator untuk menyatakan bahwa fonotaktik bahasa Sangir tidak mengijinkan dua atau lebih konsonan berderet dalam kata dan suku kata yang sama. Perhatikan deretan konsonan /mb/ pada kata [səmbau'], konsonan pertama pada kata [səmbau'] adalah konsonan nasal $/ \mathrm{m} /$. Hal yang sama juga

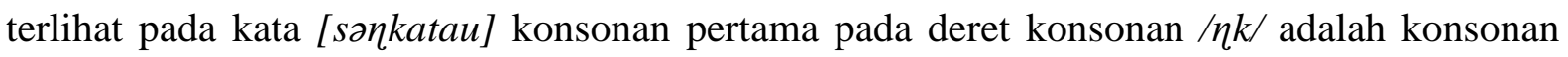


nasal $/ \eta /$. Jika deret konsonan (kecuali konsonan pertama adalah nasal) jarang ditemukan dalam bahasa sangir, maka gugus konsonan pun lebih jarang ditemukan. Untuk lebih membuktikan hal ini baiklah diperhatikan beberapa kata maupun suku kata pada tabel berikut.

Tabel 1.3

Deret Konsonan dengan Konsonan Pertama Nasal

\begin{tabular}{|c|c|c|}
\hline \multicolumn{2}{|c|}{ Kata } & Suku Kata \\
\hline kendung & 'ingat' & 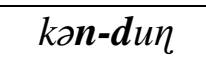 \\
\hline sembau & 'satu' & səm-bau? \\
\hline$i m b u$ & 'cium' & $I m-b u$ \\
\hline entung & 'lempar' & 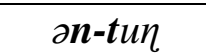 \\
\hline
\end{tabular}

Dari tabel di atas dapat disebutkan beberapa deret konsonan dengan konsonan pertama dalam deret tersebut adalah konsonan nasal yaitu $/ n d /, / n b /, / n t /$, Ins/ dan deret konsonan $/ n g /$ yang dalam pengartikulasian langsung menjadi bunyi nasal $/ \eta /$. Perhatikan bahwa $/ n d /, / n b /, / n t /, / n s /$ merupakan deret konsonan dan bukan gugus konsonan atau kluster sehingga pada pembentukan suku kata deret konsonan ini akan berada pada suku kata yang berbeda dan tidak pada satu suku kata yang sama. Gugus konsonan tidak dijumpai dalam bahasa Sangir seperti dalam bahasa Indonesia. Gugus konsonan adalah deretan dua konsonan atau lebih yang tergolong ke dalam satu suku kata yang ketika dilafalkan baik pada posisi awal, tengah, dan akhir kata. Gugus konsonan juga mencakup dua atau tiga konsonan berdampingan yang terdapat dalam satu suku kata.

\section{Koda Suku Kata Bahasa Sangir}

Ketiadaan deret konsonan (kecuali konsonan pertama adalah nasal) pada fonotaktik bahasa Sangir mengakibatkan jarang ditemukan koda pada pembentukan suku kata bahasa Sangir. Koda adalah konsonan yang tersisa di sebelah kanan inti suku kata yang setelah penentuan awalan suku kata (Michael Dobrovolskyand William DO' Grady menulis 1997:72). Suku kata bahasa Sangir umumnya hanya berupa KVKVKV mengakibatkan konsonan yang berada di sebelah kiri suku kata otomatis menjadi awalan atau onset suku kata, dan tidak ada konsonan yang tersisa untuk menjadi koda suku kata sebelumnya karena jarang ditemukan deret konsonan. Hal ini terlihat pada suku kata [ba-wi-nê] di atas /b/ dengan sedirinya menjadi onset untuk suku kata $[b a], / w /$ menjadi onset untuk suku kata [wi] dan $/ n /$ menjadi onset 
untuk suku kata [ne]. Struktur yang sama juga dapat ditemukan dalam banyak kata bahasa Sangir yang lain yaitu datu, mawu, kalu, nehoma, kado, kakanoa, humotong dan masih ada sederet kata lain dalam bahasa Sangir yang dijumpai memiliki struktur suku kata seperti ini. Dalam tabel berikut akan diuraikan pola suku kata bahasa Sangir sesuai dengan tiga unsur pembentuk suku kata yaitu Nukleus $(\mathrm{N})$, Onset $(\mathrm{O})$ dan Koda (C).

\section{Tabel 1.4}

Pola Suku Kata Bahasa Sangir

\begin{tabular}{|c|c|}
\hline Pola Suku Kata & Contoh \\
\hline $\mathrm{N}$ & $\begin{array}{l}\text { la/ pada kata /a-man' 'laki- } \\
\text { laki' }\end{array}$ \\
\hline $\mathrm{ON}$ & $\begin{array}{l}\text { /tu/ pada kata /tu-hu/ } \\
\text { 'ikut' }\end{array}$ \\
\hline NK & 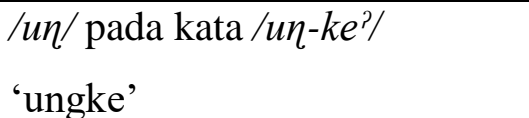 \\
\hline ONK & $\begin{array}{l}\text { /tum/ pada kata /tum-ba-en/ } \\
\text { 'hanya' }\end{array}$ \\
\hline
\end{tabular}

Koda suku kata hanya ditemukan pada deret konsonan di mana konsonan pertama adalah nasal, pada kata yang hanya memiliki satu suku kata dan pada kata yang berakhir dengan konsonan. Perhatikan suku kata [səm-bau'] di atas $/ \mathrm{m} /$ menjadi koda suku kata [səm], perhatikan $/ \mathrm{m} /$ di sini adalah konsonan nasal. Koda pada kata yang memiliki satu suku kata terlihat pada kata $[k \hat{\imath} \eta], / \eta /$ menjadi koda suku kata $[k a ̂ \eta], / \eta /$ di sini juga adalah nasal . Koda

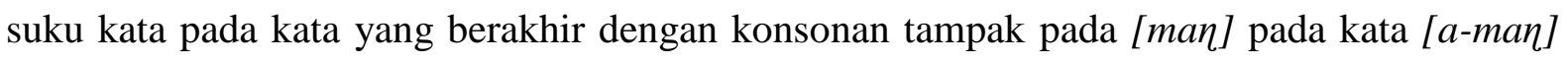
'laki-laki'Secara generalisasi mungkin dapat dikatakan bahwa jika ditemukan koda dalam suku kata bahasa Sangir, kemungkinan koda tersebut adalah konsonan nasal.

\section{Penyisipan Vokal /ə/ pada Kata Serapan}

Aspek intuitif yang muncul berdasarkan kaidah fonotaktik yang berlaku dalam suatu bahasa juga tampak pada penutur bahasa Sangir. Ketiadaan deret konsonan pada dalam fonotaktik bahasa Sangir juga memengaruhi pembentukan suku kata pada kata serapan (bahasa Indonesia atau bahasa lain yang diserap ke bahasa Sangir) bahasa Sangir. Dalam beberapa dialek bahasa Sangir ada kecenderungan untuk menyisipkan vokal / / pada kata serapan yang memiliki deret konsonan. Hal ini terjadi dengan sendirinya berdasarkan kesadaran penutur 
bahasa Sangir, yang tidak terbiasa dengan dengan deretan konsonan maupun gugus konsonan di dalam kata maupun suku kata.

Kata-kata yang diserap dari bahasa di luar bahasa Sangir yang memiliki deret konsonan maupun gugus konsonan, dianggap tidak berterima berdasarkan fonotaktik bahasa Sangir, sehingga terjadilah penyisipan vokal /ə/ diantara deret konsonan yang dijumpai dalam kata-kata serapan.Misalnya kata [pəriksa] yang dilafakan menjadi [pərikəsa] sehingga suku kata [pəriksa] dalam bahasa Indonesia yang berupa [pə-rik-sa] setelah diserap ke dalam bahasa Sangir menjadi [pərikəsa] suku katanya menjadi [pə-ri-kə-sa] yang awalnya hanya memiliki tiga suku kata setelah diserap ke dalam bahasa Sangir menjadi empat suku kata karena penyisipan vokal / $/$ pada kata tersebut. Penyisipan vokal / $/$ juga tampak pada kata [tripleks] meskipun penyisipan vokal /ol tampak tidak konsisten dalam kata ini. Bagi beberapa penutur bahasa Sangir dilafalkan sebagai [tว-ri-ple-sə] dengan menyisipkan vokal /ə/ pada sesudah konsonan / $t /$ dan sesudah konsonan /s/tetapi penyisipan vokal / / ini terjadi diantara konsonan /pl/.

\section{SIMPULAN}

Berdasarkan hasil pembahasan di atas dan teori yang dipakai penulis dalam penelitian ini maka penulis dapat menyimpulkan beberapa hal berikut ini :

1) Pembentukan suku kata bahasa Sangir dapat dibentuk baik dengan menggunakan teori dari O'Grady mapun teori Chaer sehingga dapat diketahui mana yang merupakan Nukleus (N), Onset (O) dan Koda (C).Dari pembentukan ini diketahui bahwa suku kata bahasaSangir memiliki unsur yang lengkap sebagai suku kata yaitu memiliki Nukleus (N), Onset (O) dan Koda (K)

2) O’Grady (1997) dan Chaer (2009) menjelaskan bahwa struktur suku kata merupakan deret fonem (deret vokal, deret konsonan, diftong dan kluster) yang diijinkan dalam suatu bahasa. Berikut ini beberapa hal yang ditemukan berhubungan dengan struktur suku kata bahasa Sangir. a) Struktur suku kata bahasa Sangir juga membedakan antara deretan vokal dan diftong ; b) Vokal /ə/ sesudah vokal /a/ mengalami efisiensi bunyi sedangkan vokal / $/$ / yang dilafalkan sesudah vokal /a/ tidak.Hal ini memengaruhi pembentukan suku kata; c) Bahasa Sangir memiliki empat struktur suku kata yaitu V, KV,VK dan KVK. Dalam bahasa Sangir tidak ditemukan suku kata dengan struktur, KKV, KKVK, KKVKK, VKK, KVKK, KKKV, KKKVK.

3) Jika O'Grady dalam uraiannya tentang fonotaktik bahasa Inggris menyebut bahwa dalam bahasa Inggris diijinkan tiga konsonan berderet dalam satu kata maupun suku kata, jika 
konsonan pertama adalah/s/ misalnya pada kata /structure//.Maka berikut ini adalah kaidah fonotaktik bahasa Sangir yang ditemukan dalam penelitian ini.a) Jarang atau ditemukan deretan konsonan pada kata bahasa Sangir, kecuali jika konsonan pertama adalah nasal yaitu $/ n d /, / n b /, / n t /$, /ns/ dan deret konsonan /ng/. ; b) Dalam bahasa Sangir jarang ditemukan koda suku kata, kecuali pada kata yang memiliki dereten konsonan dengan konsonan pertama adalah nasal, pada kata yang bersuku kata satu dan pada kata yang berakhir dengan konsonan. Jika ditemukan koda maka umumnya koda suku kata adalah konsonan nasal; c) Ketiadaan deret konsonan (kecuali konsonan pertama adalah nasal) pada dalam fonotaktik bahasa Sangir juga memengaruhi pembentukan suku kata pada kata serapan dengan penyisipan vokal/ə/pada beberapa kata serapan meskipun penyisipan vokal /ə/kadang tidak konsisten.

\section{DAFTAR PUSTAKA}

Achmad, H. dan Alek Abdullah. 2012. Linguistik Umum. Jakarta: Erlangga.

Bawolle, G. 1978. Struktur Bahasa Sangihe. Laporan Penelitian Departemen Pendidikan dan Kebudayaan Manado

Bawolle, G, J. Akun Danie dan Dalu Toding. 1981. Morfologi Bahasa Sangihe. Jakarta: Pusat Pembinaan dan Pengembangan Bahasa: Departemen Pendidikan dan Kebudayaan

Chaer, Abdul. 2009. Fonologi Bahasa Indonesia. Jakarta: Rineka Cipta

Chaer, Abdul. 2014. Linguistik Umum. Jakarta: Rineka Cipta

Danie, J. Akun dkk. 1998. Geografi Dialek Bahasa Sangir. Jakarta: Pusat Pembinaan dan Pengembangan Bahasa: Departemen Pendidikan dan Kebudayaan.

Kentjono, Djoko. Ed. 2003. Dasar-Dasar Linguistik Umum. Jakarta: FSUI.

Kridalaksana, Harimurti. 2008 Kamus Linguistik Edisi Keempat. Jakarta: Gramedia Pustaka Utama.

Lyons, John. Terj. I Soetikno. 1995. Pengantar Teori Linguistik. Jakarta: Gramedia Pustaka Nusa Utama.

Marsono. 1999. Fonetik. Yogyakarta: Gadjah Mada University Press .

Michael, Dobrovolsky and William D O' Grady. 1987. Contemporary Linguistic Analysis: an Introduction. Paperback.

Muslich, Masnur. 2008. FonologiBahasa Indonesia: Tinjauan Deskriptif Sistem Bunyi Bahasa Indonesia. Jakarta: Bumi Aksara. 
Nebarth, Paul dkk. 1985. Sastra Lisan Sangir Talaud. Jakarta: Pusat Pembinaan dan Pengembangan Bahasa Departemen Pendidkan dan Kebudayaan.

Odden, David. 2005. Introducing Phonology. Cambridge University Press: New York.

Parera, Jos Daniel. 1985. Pengantar Linguistik Umum: Fonetik dan Fonemik. Ende: Flores.

Pastika, I Wayan. 2012. "Kelemahan Fonologi Ejaan Bahasa Indonesia yang Disempurnakan.” Linguistik Indonesia, 30.2, 147-166.

Robins. R. H. 1992. Linguistik Umum Sebuah Pengantar. Jakarta: Kanisius.

Sariah. 2014. "Akronim yang Berfonotaktik Tak Lazim dalam Bahasa Indonesia.” Linguistik Indonesia, 32.1, 47- 61.

Sorey, Oldrie Ch. 2015. Tata Bahasa Tombulu. Yogyakarta: Gama Media.

Sudarmo. 2016. "Fonotakik Bahasa Banjar". Jurnal Bahasa Sastra dan Pembelajaran, 6.2, 278-297.

Verhaar, J. W. M. 2010. Asas-asas Lingusitik Umum. Yogyakarta: Gadjah Mada University Press. 